\title{
Dating of Iron Artefacts by Metallographical Methods
}

\section{G. Sperl*}

* Univ.Prof. Dr.phil.Dr.mont.Dipl.-Ing.; Lecturer on Historical Materials at the Universities of Leoben, Innsbruck and Vienna: researcher at the Erich-Schmid Institut für Materialwissenschaft der Österreichischen Akademie der Wissenschaften, Leoben. Now since 2002: Institut für Historische Werkstoffe (IHW-EFDZ), Mareckkai 46, A-8700 Leoben (Austria):

\section{The problem}

Iron objects of historical and prehistorical age usually are dated by their typology and finding conditions; therefore, archaeological findings can be dated well by their archaeological context. Some objects like some types of horseshoes, which are the most convincing examples, cannot be dated archaeologically when they are found near historical trade routes, and therefore the metallic structure is the only source of information for dating.

\section{Methods used}

The first help for dating are the slag inclusion; they differ clearly, when the modern system of steelmaking was introduced. So modern craftswork, often produced in a historical manner can simply be distinguished from medieaval products[1]. On the other hand the chemical composition of slag inclusions often gives a first indication for its dating (Fig.1) [2]. Historical wrought-iron contains usually $0,1-0,2 \% \mathrm{C}$, with the total range of $0,02-1,0 \% \mathrm{C}$. Modern mass-spectrometry used for dating by the $\mathrm{C} 14$-content needs some micrograms of carbon, thus using small specimens of sound metal $\left(0,01 \mathrm{~cm}^{3}\right)$ [3]; the possibilities of testing the effects of "Ostwald-ripening" are to be verified by modern testing methods concerning the iron-carbides at room temperature grown over many centuries $[4,5]$.

\section{References:}

[1] G.Sperl: Befund über ein orientalisches Serviertablett, 23.7.2001.

[2] G.Sperl, Über die Typologie urzeitlicher, frühgeschichtlicher und mittelalterlicher Eisenhüttenschlacken; in: Studien zur Industrie-Archäologie VII, Österr. Akademie der Wissenschaften, Wien, 1980 On the Typology of slags from Iron-making in Prehistoric and Medieval Times)

[3] G.Sperl, Datieren von Eisenfunden aus Gefügeuntersuchungen, to be published in: Sonderbände der Praktischen Metallographie, Tagung Leoben 2002.

[4] Björklund S., L.F. Donaghey, M.Hiller: The Effect of Alloying Elements on the Rate of Ostwald Ripening of Cementite in Steel, in:Acta Met. 20(1972) 867-874

[5] Criado Antonio José, Juan Antonio Martínez, Rafael Calabrés, Luisa María Rodríguez, José Manuel Jiménez, Mattias Karlsson:Durch Alterungsprozesse entstandenes Gefüge in historischen und archäologischen Gegenständen aus Stahl, in: Prakt. Metallogr. 37 (2002),6, 315-324]

Note on this publication: there couldn't be found the way of dating the sword "Tizona" of the spanish commander Cid Campeador ( $11^{\text {th }}$ cent.) that has been dated by the method of measuring the size of the carbides of interest; therefore fundamental research on the growth of th epsilon-carbide, segregated at room-temperature is to be done in Leoben. 


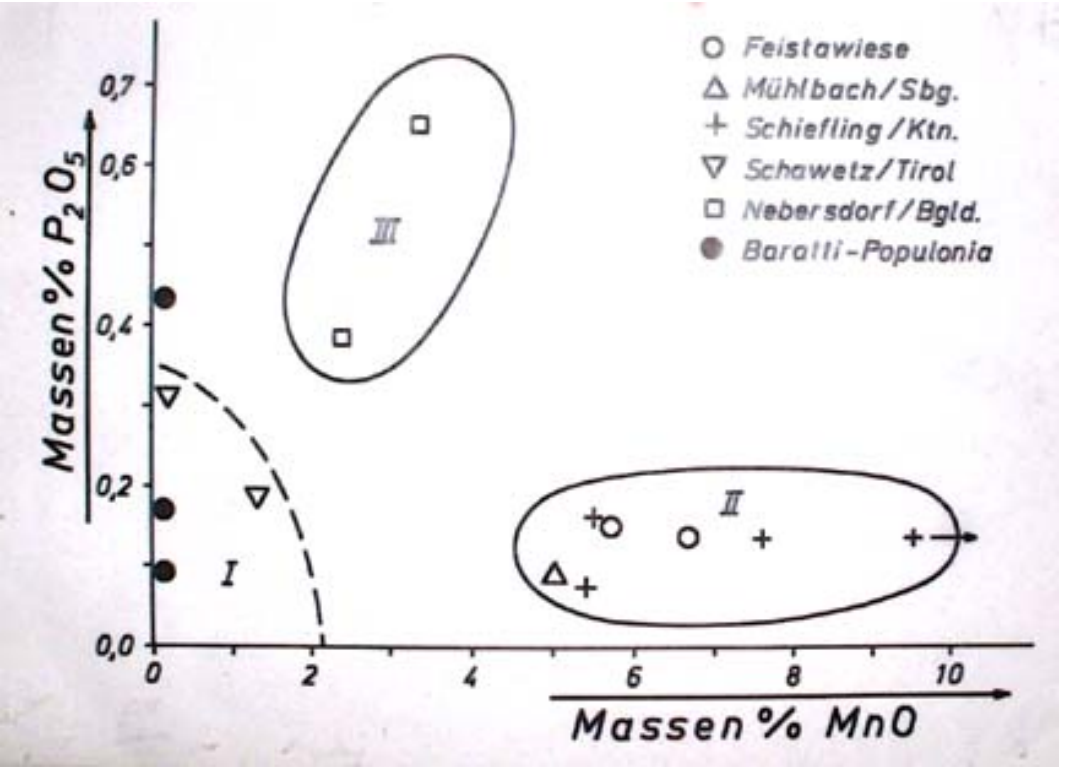

FIG.1 In the slag inclusions in historical wrought-iron (about 1 Vol-\%) the composition of the original ore can be found by x-ray microprobe testing. The most typical elements are phosphorous and manganese characterizing different types of iron ore deposits. Here the group (I) characterizes the ores from the Ile of Elba (etruscan-roman); (II) the alpine sideritic res used in celtic-roman times and the middle ages, (III) the eastern ores of Burgenland (Austria and Sopron (Hungary) [1].

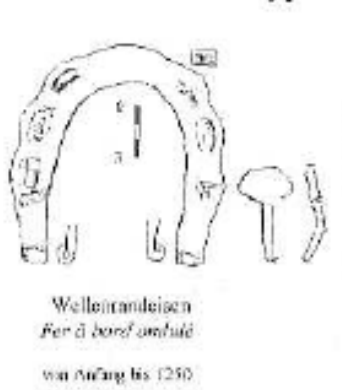

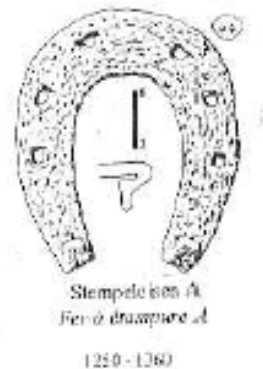

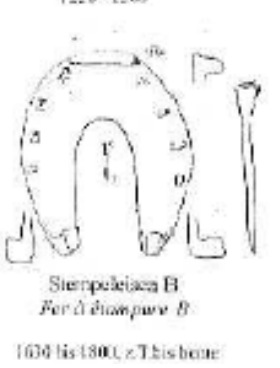

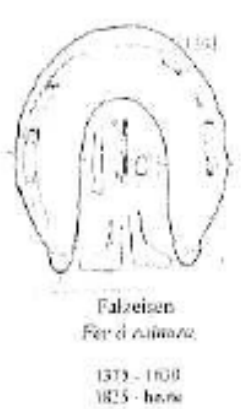

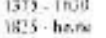

FIG.2. The use of horseshoes is very important for moving gooods and persons over long distances, therefore the discussion of the beginning of their use is still on the way, specially when the archaeological dating is uncertain; we know the "hipposandals" used in antiquity (greek-roman) but no direct indication to the use of the modern type horseshoes (with the nails) could be found. So the dating from the metallic structure is an interesting way of solving the problems of the beginning[3]. 